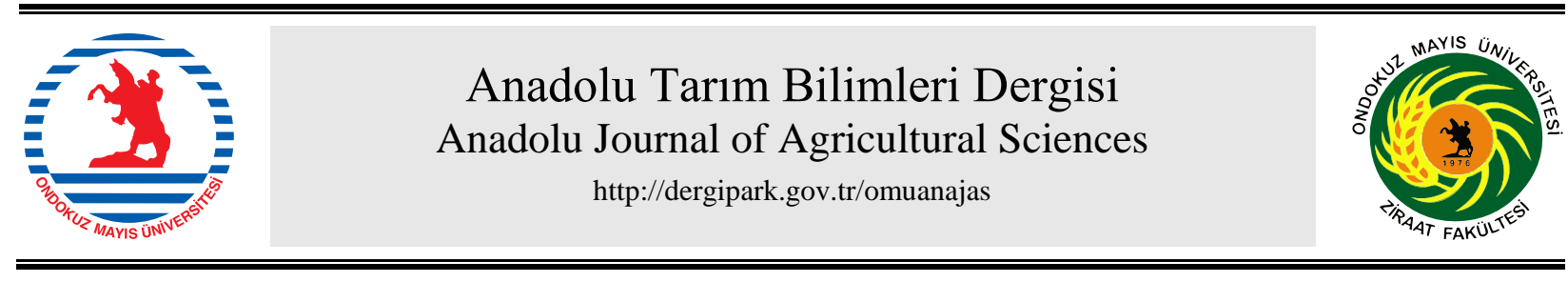

Araştırma/Research

Anadolu Tarım Bilim. Derg./Anadolu J Agr Sci, 32 (2017)

ISSN: 1308-8750 (Print) 1308-8769 (Online)

doi: 10.7161/omuanajas.319335

\title{
Enerji dengesine dayalı evapotranspirasyon haritalamada içsel kalibrasyon için temel hücrelerin görüntü filtreleme yaklaşımı ile seçilmesi
}

\author{
Sakine Çetin*, Eyüp Selim Köksal, Emre Tunca \\ Ondokuz Mayls Üniversitesi, Ziraat Fakültesi, Tarımsal Yapılar ve Sulama Bölümü, \\ *Sorumlu yazar/corresponding author: sakinecetin@msn.com \\ Geliş/Received 06/06/2017～Kabul/Accepted 18/09/2017
}

\begin{abstract}
ÖZET
Evapotranspirasyon (ET) haritalama çalışmaları, su kaynakları yönetiminde hidrolojik su bütçelerinin hazırlanması ve sulu tarım alanlarında kullanılan su miktarlarının tahmin edilmesi gibi konularda büyük öneme sahiptir. Son yıllarda gelişen uydu teknolojileri sayesinde ET haritalama olanakları giderek artmaktadır. ET haritalarının hazırlanması amacıyla geliştirilmiş modellerin hemen hepsi (METRIC, SEBAL vb.) temel bileşenleri gizli 1sı akısı (LE), hissedilebilir 1sı akısı (H), net radyasyon (Rn) ve toprak ısı akısı $(\mathrm{G})$ olan enerji dengesine dayanmaktadır. Uydu görüntülerinden elde edilen veriler ve meteorolojik verilerin bir arada kullanıldığ bu modellerde en önemli aşamalardan birisi hissedilebilir 1sı akısı $(\mathrm{H})$ hesaplamasıdır. METRIC ve SEBAL modellerinde H'nin hesabı bir içsel kalibrasyon işlemi içermektedir. Bu kalibrasyon, çalışma alanından seçilen soğuk ve sıcak hücre olarak adlandırılan iki uç koşula dayanmaktadır. Soğuk hücre, ET' nin potansiyel düzeyde olduğu ve sıcak hücre ET' nin en az düzeyde olduğu koşulları temsil etmektedir. Bu nedenle soğuk ve sıcak hücrenin seçilmesi, elde edilen ET haritasının doğruluğu üzerinde önemli bir etkiye sahiptir. Söz konusu hücrelerin tarım alanlarından seçilmesi gerekmektedir ve çalışma sahası büyük olduğunda çeşitli filtreleme eşitliklerine ihtiyaç duyulmaktadır. Bu çalışmanın amacı, güncel bir yaklaşım olan METRIC modelinde soğuk ve sıcak hücrelerin seçimini kolaylaştıracak ve böylece ET haritalarının doğruluğunu arttıracak filtreleme yöntemlerinin geliştirilmesi ve uygulanmasıdır. Çalışma, yarı nemli (Bafra) ve yarı kurak (Suluova) iklim özelliklerine sahip iki ayrı bölge için yürütülmüştür. Hesaplamalar için Landsat 8 uydu görüntüleri kullanılmıştır. Filtreleme amacıyla geliştirilen eşitlikler normalize edilmiş vejetatif değişim indeksi (NDVI) ve yüzey sıcaklığına (Ts) dayandırılmıştır. Geliştirilen filtreleme yöntemi ile soğuk ve sıcak hücre seçimi başarılı ve kolay bir biçimde gerçekleştirilmiştir. Filtreleme uygulanması, bir kişinden diğerine değişebilecek soğuk ve sıcak hücre seçimine belli bir standart getirmiştir. Filtreleme uygulaması ile soğuk ve sıcak hücre seçimi ET haritalamada doğruluğu arttırmış ve önemli düzeyde zaman kazandırmıştır.
\end{abstract}

Selection of anchor pixels by a using image filtering approach for internal calibration step of evapotranspiration mapping through energy balance

\section{ABSTRACT}

Evapotranspiration (ET) has a great importance for calculation of hydrologic water budget in water resource management and estimation of irrigation water amount in agricultural water management. In recent years, ET mapping opportunities have been gradually increased by the development of satellite technologies. Almost all models (METRIC, SEBAL etc.) developed for ET mostly depends on energy balance, the main components of which are latent heat flux (LE), sensible heat flux $(\mathrm{H})$, net radiation $(\mathrm{Rn})$ and soil heat flux (G). METRIC and SEBAL are two important energy balance based models. In order to run these models, the data obtained from satellite images and meteorological stations should be used together, and one of the most important step is the calculation of sensible heat flux $(\mathrm{H})$. In METRIC and SEBAL models, the calculation of $\mathrm{H}$ contains an internal calibration process which depends on two selected anchor pixels called hot and cold. Cold pixel represents a condition of ET at potential level and hot pixel represents a situation with ET at zero level. Therefore, the selection of hot and cold pixels have an important effect on the accuracy of ET maps. Anchor pixels should be selected from agricultural areas, and the filtration equations are required in the case of the large study area. The
Anahtar Sözcükler: ET haritalama Landsat 8 Enerji Dengesi Soğuk hücre Sicak hücre

Keywords: ET mapping Landsat 8 Energy Balance Anchor pixel 
main purpose of this study was to develop filtration equations for facilitating the selection of anchor pixels for a current model approach, METRIC and thus improve the accuracy of ET maps. This study was carried out for two separate regions; one of them having sub-humid (Bafra) and the other having semi-arid (Suluova) climate conditions. Landsat 8 satellite images were used for calculations. The equations developed for filtration purposes were based on the normalized difference vegetation index (NDVI) and surface temperature (Ts). By using the filtration method developed in this study, the selection of anchor pixels was achieved correctly and easily. This filtration method standardized the anchor pixel selection, which could vary from one person to another. The application of filtration improved the accuracy of ET maps and offered a significant opportunity to save time.

\section{Giriş}

Evapotranspirasyonun (ET) hidrosfer, atmosfer ve biyosferin enerji ve kütle değişimlerinde önemli rol oynadığ 1996). Evapotranspirasyon, tarımsal alanlarında yăğış ve sulama ile toprakta depolanan suyun eksilmesinde başlica etmendir (Gowda ve ark., 2008b). Tarımda su kullanım etkinliğini arttırmak için alınacak her türlü tedbir için ET'nin güvenilir biçimde tahmin edilmesi gerekmektedir. ET değerleri tarımsal uygulamalarla birlikte meteorolojik koşullara bağlı olarak bölgesel ve mevsimsel olarak değişebilmektedir (Hanson 1991). ET'nin zamansal ve konumsal değişimlerinin belirlenmesi özellikle su kaynaklarının planlanması ve yönetimi açısından da oldukça önemlidir.

Toprak su bütçesine dayanan yöntemler ile ET doğru bir biçimde ölçülebilir. Toprak su bütçesi elemanları ise lizimetre sistemleri ile güvenli bir biçimde belirlenebilmektedir. Bunun yanı sıra ET, Bowen oranı (BR), Eddy kovaryans (EC) teknikleriyle ve uzaktan algılamaya dayanan enerji dengesi modelleri ile belirli seviye doğrulukla izlenebilir. Fakat BR ve EC teknikleri ile bölgesel ölçekte ET'nin konumsal dağılımları hakkında bilgi elde edilememektedir. $\mathrm{Bu}$ nedenle uzaktan algılanmış verilerin kullanıldığı enerji dengesi tabanlı modeller ET'nin alansal dağılımını da tahmin etmek için daha uygundur (Allen ve ark., 2007a). Günümüze kadar uzaktan algılanmış veriler ile meteorolojik verileri bir arada kullanan çok sayıda model geliştirilmiştir (Gowda ve ark., 2008a). Bu tür modeller sayesinde zaman etkili bir şekilde kullanılarak daha az maliyetle, daha doğru ve güvenilir ET tahmini yapılabilmektedir (Polhamusa ve ark., 2013).

Enerji dengesine dayanan evapotranspirasyonun haritalanmasında yüksek çözünürlük ve içsel kalibrasyon (METRIC) modeli ET tahmininde yaygin bir şekilde kullanılmaktadır (Allen ve ark., 2005; Kjaersgaard ve ark., 2009). METRIC modeli enerji dengesi bileșenlerinden net radyasyon (Rn), toprak 1s1 akıs1 (G), hissedilebilir 1s1 akıs1 (H) ve gizli 1s1 akısı'nın (LE) ayrı ayrı tahmin edilmesine dayanmaktadır. METRIC modelinde $\mathrm{H}$ hesabı, oldukça karmaşıktır ve içsel bir kalibrasyon ve iterasyon işlemlerini kapsamaktadır. İçsel kalibrasyon çalışma alanının uydu görüntüsünde seçilecek sıcak ve soğuk hücrelere ait enerji dengesi bileşenlerine dayanmaktadır. Sicak ve soğuk hücre seçiminde literatürde belirgin bir matematiksel yöntem olmamakla birlikte, bu hücrelerin genel özellikleri net bir biçimde tanımlanmıştır. Sıcak hücre bitki örtüsünden yoksun ve ET'nin hemen hemen hiç gerçekleşmediği tarım arazilerine ait hücrelerden seçilmelidir. Soğuk hücre ise vejetasyonun yoğun olduğu, su eksikliğinin olmadığı ve potansiyel düzeyde ET’nin gerçekleşebildiği tarım arazilerine ait hücreler arasından seçilmelidir. METRIC modeli ile ET'nin haritalanmasında sıcak ve soğuk hücrelerin seçilmesi ET'nin hangi aralıkta (en yüksek ve en düşük) değişeceğini belirleyen önemli bir aşamadır (Allen ve ark., 2005; Allen ve ark., 2007; Singh ve Irmak, 2011).

$\mathrm{Bu}$ çalışmanın amacı, METRIC modelinde içsel kalibrasyon için gerekli olan sıcak ve soğuk hücrelerin daha kolay belirlenmesi için bir filtreleme uygulanmasının geliştirilmesi ve değerlendirilmesidir. Çalışma yarı kurak (Suluova) ve yarı nemli (Bafra) iklim özelliklerine sahip iki ayrı bölge için yürütülmüsşür. Filtreleme işlemlerinde çeşitli yüzey sıcaklığı (Ts) ve Normalize Edilmiş Vejetatif Değişim İndeksi (NDVI) sınır değerleri test edilmiştir. Bu sınır değerlere göre iki farklı iklim bölgesinde seçilen soğuk ve sıcak hücreler karşılaştırılmış ve ET haritalarına olan etkileri değerlendirilmiştir.

\section{Materyal ve Yöntem}

\subsection{Materyal}

Çalışma yarı kurak iklim özelliği gösteren Amasya ili Suluova ilçesi ve yarı nemli iklime sahip Samsun ili Bafra ilçesi tarım arazileri için yürütülmüştür (Şekil 1). Orta Karadeniz Bölgesi'nin iç kısımlarında yer alan Suluova, Amasya'nın $25 \mathrm{~km}$ batısında yer almaktadır. Başlıca temel geçim kaynağı tarımdır. Tersakan Çayı ilçenin en önemli su kaynağıdır ve bölgede çoğunlukla sulu tarım yapılmaktadır. Son 30 yıllık iklim verilerine göre, ortalama sıcaklık değeri $13.7{ }^{\circ} \mathrm{C}$, ortalama oransal nem değeri $\% 60.0$ ve ortalama yıllık toplam yă̆ış değeri ise $460.0 \mathrm{~mm}$ ' dir. Orta Karadeniz Bölgesi'nin kıy1 kesiminde bulunan Bafra, Samsun merkezine yaklaşık $50.0 \mathrm{~km}$ uzaklıktadır. Temel geçim kaynağı tarımdır. Kızılırmak Bafra'nın en önemli su kaynağıdır ve bölgede çoğunlukla sulu tarım yapılmaktadır. Son 30 yıllık iklim verilerine göre, ortalama sıcaklık değeri $14.5{ }^{\circ} \mathrm{C}$, ortalama oransal nem değeri $\% 73.0$ ve ortalama yıllık toplam yağış değeri ise $694.0 \mathrm{~mm}$ 'dir (Anonim, 2017). 


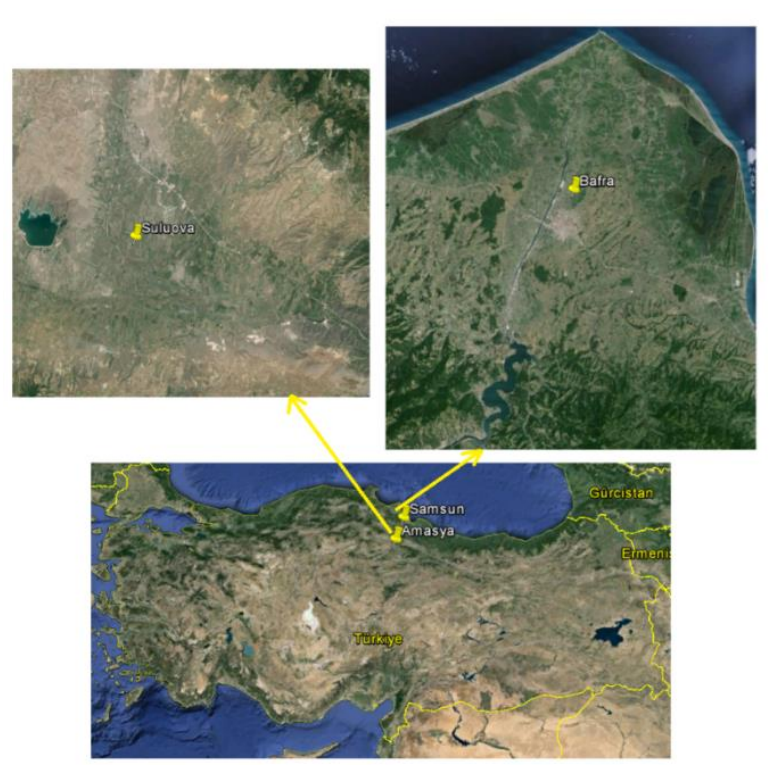

Şekil 1. Çalışma alanı coğrafik konumu.

$\mathrm{Bu}$ çalışma için Amasya ve Samsun merkezli 2013 yılına ait 25 Haziran tarihinde çekilen 2 adet Landsat 8 uydu görüntüsü temin edilmiştir. $\mathrm{Bu}$ görüntülerin işlenmesinde saatlik ve günlük iklim verilerinden hava sıcaklığı (Ta), atmosferik basınç (P), oransal nem (RH), güneş radyasyonu (Rs) ve rüzgar hızı (u) kullanılmıştır. Veriler Meteoroloji Genel Müdürlüğü’ne (MGM) bağlı meteoroloji istasyonundan temin edilmiştir. Çalışmada uydu görüntülerinin işlenmesinde ve sayısal veri elde etmede Erdas Imagine 10.0, haritalama çalışmalarında Global Mapper 13.0 ve Arc GIS 10.0 bilgisayar yazılımları kullanılmıştır.

\subsection{Metot}

Çalı̧̧mada ET'nin haritalanmasında uydu görüntüleri ve iklim verileri kullanılarak yüzey enerji dengesine dayanan METRIC modeli kullanılmıştır. Modelin dayandığı enerji dengesi genel olarak Eşitlik 1 'de verildiği gibidir.

$$
\mathrm{LE}=\mathrm{Rn}-\mathrm{H}-\mathrm{G}
$$

Eşitlikte tüm birimler $\mathrm{Wm}^{-2}$ cinsindendir (Allen ve ark., 2005; Allen ve ark., 2007; Kjaersgaard ve ark., 2009; Gowda ve ark., 2011). Enerji dengesinin tüm bileşenleri kullanılan uydu görüntülerinin her bir hücresi (pikseli) için ayrı ayrı hesaplanmıştır. Bu kapsamda ilk önce $\mathrm{Rn}$ haritaları daha sonra sırasıyla $\mathrm{G}$ ve $\mathrm{H}$ haritaları elde edilmiştir. Son olarak LE haritaları oluşturulmuştur. LE haritalarından anlık ET haritaları oluşturulmuştur. Anlık ET nin günlük ET ye dönüştürülmesinde uzun boylu bitki için hesaplanan saatlik ve günlük referans bitki su tüketimi $\left(\mathrm{ET}_{\mathrm{r}}\right)$ değerleri kullanılmıştır (Allen 2005a, 2007). $E T_{r}$ hesabında ise detayları ASCE-EWRI (2005)'de verilen Standardize Penman Monteith eşitliklerinden yararlanılmıştır.
Enerji dengesi bileşenlerinin hesabında gerekli olan vejetasyon indekslerinden albedo $(\alpha)$, Normalize Edilmiş Vejetatif Değişim İndeksi (NDVI), Toprak Yansımalarını Dikkate Alan Vejetasyon İndeksi (SAVI) ve Yaprak Alan İndeksi (YAI) ayrı ayrı hesaplanmıştır. Bununla birlikte termal bant verisi kullanılarak yüzey sıcaklığı (Ts) hesaplamaları yapılmışsır. Söz konusu hesaplamalarda Allen ve ark. (2007)'de verilen yöntemler kullanılmıştır.

Enerji dengesi bileşenlerinden $\mathrm{H}$, oldukça karmaşı bir algoritmaya sahiptir. H, bitki seviyesi ile bitkinin üzerinde belirli bir seviye arasındaki ısının değişimine tesir eden enerjiyi açıklamaktadır (Bastiaanssen ve ark., 1998a, 1998b; Bastiaanssen ve Boss, 1999; Bastiaanssen ve ark., 2001; Allen ve ark., 2005; Allen ve ark., 2007). $H$ hesabına ilişkin en temel eşitliklerden birisi Eşitlik 3'de verilmiştir. Burada, $\rho$ havanın yoğunluğu $\left(\mathrm{kg} \mathrm{m}^{-3}\right), \mathrm{C}_{\mathrm{p}}$ hava sabitesi $\left(\mathrm{J} \mathrm{kg}^{-1} \mathrm{~K}^{-1}\right)$, dT yüzey sıcaklığı ile atmosfer sicaklığı arasındaki fark $\left({ }^{\circ} \mathrm{C}\right)$ ve $\mathrm{r}_{\text {ah }}$ aerodinamik dirençtir $\left(\mathrm{s} \mathrm{m}^{-1}\right)$.

$H=\frac{\rho \times c_{p \times d T}}{r_{a h}}$

Hissedilebilir 1s1 akısı hesabında dT ve $r_{a h}$ hesabı önemli aşamalardan birisidir. Bu parametreler bir uydu görüntüsünün her bir hücresinde farklı olabilmektedir. METRIC modelinde dT hesabında ET'nin potansiyel düzeyde gerçekleşebildiği (soğuk hücre) ve hemen hemen hiç gerçekleşmediği koşulları (sıcak hücre) dikkate alan bir içsel kalibrasyon işlemi geliştirilmiştir. Sıcak ve soğuk hücreler ilgili görüntüler kullanılarak seçilmektedir. Hesaplanacak olan $\mathrm{H}$ ve dolayısı ile ET değerlerinin doğruluk seviyesi, bu seçimlerin doğruluğuna dayanmaktadır. METRIC modelinde sıcak hücre bitki örtüsünden yoksun çılak ve kurak tarım arazilerine ait hücre ve soğuk hücre vejetasyonun yoğun olduğu ve potansiyel düzeyde $\mathrm{ET}$, nin gerçekleşebileceği kadar su eksikliğinin olmadığı tarım arazilerine ait hücre olarak tanımlanmaktadır. Buna göre soğuk ve sıcak hücrelerde enerji dengesinin sırasıyla Eşitlikler 3, 4 ve 5' de verildiği gibi olduğu kabul edilmektedir. Eşitlik 4 soğuk hücre için LE' nin tahmin edilmesi amacıyla geliştirilmiştir. Sıcak hücrede ise LE' nin yaklaşık olarak sıfır olduğu varsayılmaktadır (Allen ve ark., 2007).

$$
\begin{aligned}
& \mathrm{H}_{\text {soğuk }}=\mathrm{Rn}-\mathrm{G}-\mathrm{LE}_{\text {soğuk }} \\
& \mathrm{LE}_{\text {soğuk }}=1.05 \times \lambda \times \mathrm{ET}_{\mathrm{r}} \\
& \mathrm{H}_{\text {stcak }}=\mathrm{Rn}-\mathrm{G}-\mathrm{LE}_{\text {stcak }}
\end{aligned}
$$

Eşitliklerde $\mathrm{H}_{\text {soğuk }}$ soğuk hücre için hesaplanan $\mathrm{H}$, $\mathrm{LE}_{\text {soğuk }}$ soğuk hücre için hesaplanan $\mathrm{LE}, \mathrm{ET}_{\mathrm{r}}$ uzun boylu bitki için hesaplanan saatlik referans bitki su tüketimi, $\mathrm{H}_{\text {sicak }}$ sicak hücre için hesaplanan $H$ ve $L_{\text {sicak }}$ sicak hücre için hesaplanan LE'yi ifade etmektedir.

Yukarıda verilen bilgilere göre sıcak ve soğuk hücrenin seçimi, görüntüdeki tarım arazilerine ait bölümlerden yapılabilmektedir. Çalışmada, filtreleme 
eşitliklerinde vejetasyon göstergesi olarak NDVI ve ET göstergesi olarak Ts haritaları kullanılmıştır. İşlenen uydu görüntülerinde, tarım arazilerinin yaklaşık en yüksek ve en düşük NDVI ve Ts değerleri genel olarak belirlenmiştir. Ardından ilgili yazılım aracılığı ile soğuk hücre için NDVI değeri yüksek (örneğin NDVI $>0.8$ ) ve sıcak hücre için NDVI değeri düşük (örneğin NDVI<0.15) olan bölgelerin yüzey sıcaklığı haritaları $\mathrm{Ts}_{\text {soğuk }}$ ve $\mathrm{Ts}_{\text {stcak }}$ olarak isimlendirilmiş ve her biri ayrı görüntü dosyası olarak saklanmıştır. Filtrelemede 2. aşama, $\mathrm{Ts}_{\text {soğuk }}$ ve $\mathrm{Ts}_{\text {sıcak }}$ isimli dosyalarda tarım arazilerine ait olan en soğuk ve en sicak hücrelerin seçimi yapılmıştır (Örneğin soğuk hücre için $T s<295$ (K) ve sicak hücre için Ts $>307(\mathrm{~K}))$. Bu görüntü dosyalarındaki Ts değerlerinin değişim aralıkları ilgili yazılımın genel istatistiksel sonuç bölümünden yararlanılarak elde edilmiștir. Soğuk ve sıcak hücre için elde edilen filtrelenmiş Ts haritaları kayıt edilmiştir. Hücre sayısı azaltılan bu haritalar kullanılarak soğuk ve sıcak hücre seçimi yapılmışıtır. Bu seçimlerin ardından detayları Tasumi ve ark. (2008) ve Allen ve ark. (2007) verilen iterasyon işlemleri uygulanarak rah değerleri hesaplanarak $\mathrm{H}$ hesabı tamamlanmış ve ET haritaları elde edilmiştir.

\section{Bulgular ve Tartışma}

\subsection{Referans bitki su tüketimi bulguları}

Çalışmada kullanılan Landsat 8 uydu görüntüsünün çekim tarihi (25 Haziran 2013) ve saati (11:17) için temin edilen ortalama saatlik iklim verileri, bu iklim verilerinden hesaplanan buhar basıncı açığı (VPD) ve saatlik $\mathrm{ET}_{\mathrm{r}}$ değerleri Çizelge 1'de verilmiştir. Çizelgede görüldüğ̈̈ gibi, uydu görüntüsünün çekildiği zaman diliminde Samsun'da Amasya'ya göre Ta değeri daha düşük ve $R H$ değeri ise daha yüksektir. Ta ve $R H$ değerleri kullanılarak hesaplanan VPD değerlerinin Amasya'da daha yüksek olduğu görülmektedir. Yarı kurak bölgede bulunan Amasya'da yarı nemli bölgede bulunan Samsun'a göre saatlik $\mathrm{ET}_{\mathrm{r}}$ değeri daha düşük olarak hesaplanmıştır. Çalışmada ayrıca günlük iklim verileri de kullanılmış ve bu verilerden günlük $\mathrm{ET}_{\mathrm{r}}$ değerleri hesaplanmıştır. Saatlik $\mathrm{ET}_{\mathrm{r}}$ 'ye benzer olarak günlük $\mathrm{ET}_{\mathrm{r}}$ değeri Amasya'da $9.31 \mathrm{~mm}$ iken Samsun için bu değer $5.72 \mathrm{~mm}$ ' dir. Bu iklim özelliklerine göre uydu görüntüsünün çekildiği günde ve saatte çalıșmada ele alınan iki farklı bölgede atmosferin buhar talebi oldukça farklıdır. Bu durumun her iki bölgede tarım arazilerinin ET özellikleri üzerinde etkili olacağı değerlendirilebilir. $\mathrm{Bu}$ etki genel olarak su açığı olmayan alanlarda ET' nin en üst sevide, su eksikliği olan alanlarda ET'nin daha düşük seviyede gerçekleşmesine neden olmaktadır. Bu nedenle Amasya iline bağlı Suluova ve Samsun iline bağlı Bafra Ovası'ndaki tarım alanlarında farklı su eksikliği koşullarında en yüksek ET'lerde fark olabileceği düşünülebilir.
Çizelge 1. Samsun ve Amasya merkezli uydu görüntülerinin çekim tarihi ve çekim saati için temin edilen ortalama saatlik iklim verileri, $\mathrm{VPD}$ ve $\mathrm{ET}_{\mathrm{r}}$ değerleri.

\begin{tabular}{ccccccc}
\hline $\begin{array}{c}\text { Uydu } \\
\text { Görüntüsü }\end{array}$ & $\begin{array}{c}\mathrm{Ta} \\
\left({ }^{\circ} \mathrm{C}\right)\end{array}$ & $\begin{array}{c}\mathrm{Rs} \\
\left(\mathrm{Mj} \mathrm{m}^{-2}\right. \\
\left.\text { saat }^{-1}\right)\end{array}$ & $\begin{array}{c}\mathrm{u}_{2} \\
\left(\mathrm{~ms}^{-1}\right)\end{array}$ & $\begin{array}{c}\mathrm{RH} \\
(\%)\end{array}$ & $\begin{array}{c}\mathrm{VPD} \\
(\mathrm{kPa})\end{array}$ & $\begin{array}{c}\mathrm{ET}_{\mathrm{r}} \\
(\mathrm{mm} \\
\left.\text { saat }^{-1}\right)\end{array}$ \\
\hline Samsun & 25.05 & 1.13 & 2.25 & 67.2 & 1.04 & 0.18 \\
\hline Amasya & 30.7 & 1.14 & 1.5 & 25.5 & 3.29 & 0.45 \\
\hline
\end{tabular}

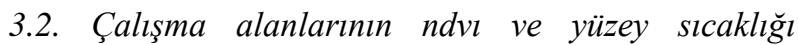 haritalarl}

Çalışma kapsamında Amasya ve Samsun merkezli 25 Haziran 2013 tarihli uydu görüntüleri işlenerek tüm uydu görüntüsü için NDVI haritaları oluşturulmuştur. Bu haritalarda çalışma alanları olan Suluova ve Bafra ovası kesilerek sırasıyla Şekil 2 ve 3'de verilmiştir. NDVI değeri 1.0'e yakın olan hücreler, vejetasyonun yoğun olduğu sulu tarım alanlarını, 0.0 'a yakın olan hücreler ise vejetasyonun az olduğu daha çok kuru tarım yapılan alanları ya da bitki bulunmayan arazi yüzeylerini göstermektedir. Negatif değerler ise su yüzeylerini göstermektedir. Allen ve ark. (2010) tarafindan verilen ve Güney Idaho'da yürütülen bir araştırma sonucuna göre NDVI'ın 0.0 ile 1.0 arasında değişim gösterdiği ve bitki gelişme dönemlerinde farklı değerlere sahip olduğu ifade edilmiştir. Amerika'da yapılan başka bir çalışmada, NDVI'ın 0.0 ile 1.0 arasında değişim gösterdiği ve bitki gelişme dönemleri boyunca farklı değerler aldığı belirtilmiştir (Kamble ve ark., 2013).

Çalışma kapsamında elde edilen NDVI haritaları daha sonra sicak ve soğuk hücre seçiminde kullanılmıştır. Görüntünün çekildiği tarihte (25 Haziran 2013) sulu tarım yapılan Suluova'da ayçiçeği, buğday, arpa, şeker pancarı, misır, soğan ve patates gibi tarla bitkileri bulunmaktadır. Bu tarihte şeker pancarı ve mısır bitkileri gelişme dönemlerinde, ayçiçeği, arpa, soğan ve patates bitkileri orta dönemlerinde, buğday bitkisi ise son dönemindedir (Tagem, 2016). Suluova tarım arazilerini içeren Şekil 2 incelendiğinde, Yedikır Barajı'nın üst kısımlarında, alt kısımlarına ve yan bölgesinde kalan tarım arazilerine göre NDVI değerlerinin daha düşük ( 0.0 ile 0.50 arasında) olduğu görülmüştür. Bunun nedeni, bu bölgelerde kot farkının diğer bölgelere göre daha yüksek olması ve bu bölgelerin barajdan sulama amaciyla su kullanamamasıdır. $\mathrm{Bu}$ durum bölgede yağışa dayalı üretim yapılan bitkilerin hasat tarihine yaklaştığını ya da çıplak arazi yüzeylerinin olduğunu göstermektedir. Yedikır Barajı'nın altında ve yan tarafinda kalan tarım arazilerinde ise, ortalama NDVI değeri yaklaşı 0,70 olup barajın üst kısımlarına göre daha yüksektir. Bunun nedeni, bu bölgelerde bulunan parsellerin barajdan sulama amaciyla su kullanmasidır. Ayrica bu parsellerde yetiştirilen çoğu bitki gelişme ve orta dönemlerinde olduğu için vejetasyon seviyeleri daha 


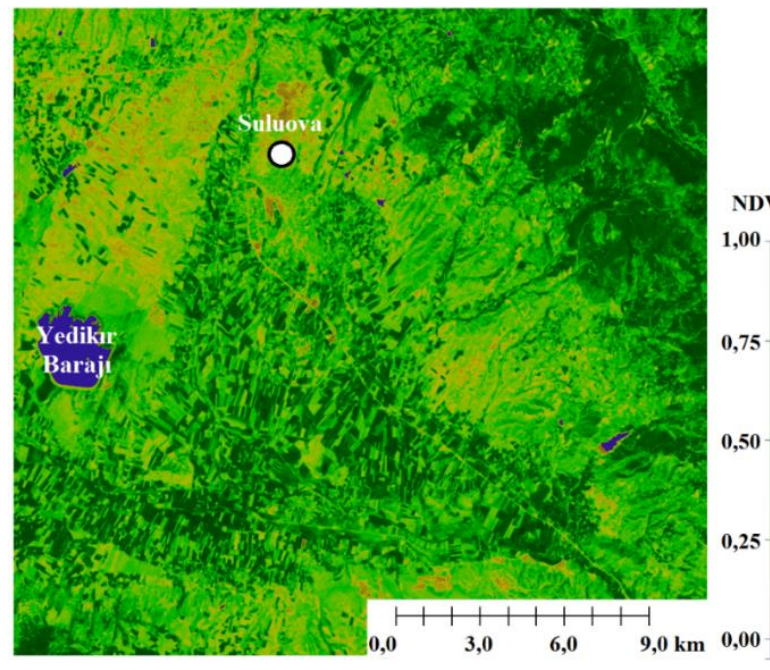

Şekil 2. Amasya merkezli uydu görüntüsünden elde edilen çalışma alanına ait NDVI haritası.

yüksektir. Tasumi ve ark. (2005)'de sulu tarım yapılan alanların yüksek, çıplak ve kurak toprak yüzeylerinin ise daha düşük NDVI değerine sahip olduğu açıkça belirtilmiştir.

Bafra Ovasını ikiye ayıran Kızılırmak'ın sağ ve sol sahillerinde bulunan tarım arazileri incelendiğginde, her iki bölgede ortalama NDVI değerlerinin birbirine yakın olduğu gözlenmiştir (Şekil 3). Landsat 8 uydusunun çekim tarihi olan 25 Haziran 2013'de, Bafra Ovası'nda çeltik, biber, domates, hiyar, karpuz, kavun, misır, fasulye, patlıcan gibi bitkiler bulunmaktadır. Bu bitkilerden çeltik, biber, domates, hıyar, karpuz, kavun, mısır, fasulye ve patlıcan bitkileri gelişme dönemlerindedir (Tagem, 2016). Bafra Ovası'nda bulunan sağ ve sol sahilde ortalama NDVI değerlerinin birbirine yakın olması, yetiştirilen bitkilerin gelişme dönemlerinde vejetasyon seviyelerinin hemen hemen aynı düzeyde olduğunu göstermektedir.

Çalışma kapsamında Amasya ve Samsun merkezli Landsat 8 uydu görüntüleri kullanılarak Ts haritaları oluşturulmuştur. Çalışma alanları olan Suluova ve Bafra ovası kesilerek sırasıyla Şekil 4 ve 5'de verilmiştir. Her iki şekilde de su yüzeylerindeki (örneğin Kızılırmak) Ts değerlerinin, tarım arazileri ve diğer alanlara göre daha düşük olduğu tespit edilmiştir. Ormanlık alanlarda ise Ts değerleri su yüzeylerine göre daha yüksek, tarım arazileri ve diğer alanlara göre daha düşüktür.

Sobrinoa ve ark. (2004)'de tarafindan verilen bir çalışmada, farklı toprak tipleri ve yüzeylerinde (Kırmızımsı asma toprağı, hafif bünyeli az bitki örtüsüne sahip toprak, kahverengi toprak, karışık toprak (kahverengi ve hafif), killi topraklar, ormanlar) Ts'nin farklı değerler aldığı ifade edilmiştir. Yapılan diğer bir çalışmada ise farklı arazi kullanımlarında Ts değerlerinin değişiklik gösterdiği belirtilmiştir (Mallick ve ark., 2008).

Çalışmada tarım arazileri için Ts haritalarından tespit edilen en düşük ve en yükssek Ts değerleri sıcak

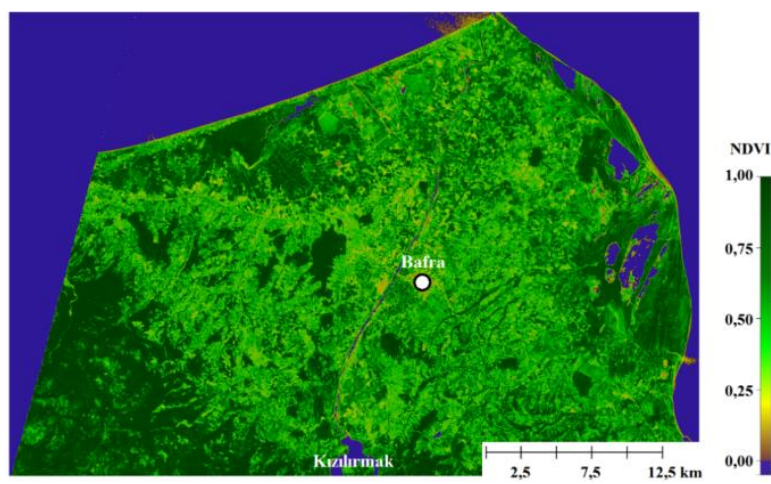

Şekil 3. Bafra merkezli uydu görüntüsünden elde edilen çalışma alanına ait NDVI haritası.

ve soğuk hücre seçiminde kullanılmıştır. Şekil 4'de Suluova tarım arazilerinde Ts değerleri genel olarak 295.0 ile $311.0 \mathrm{~K}$ arasında değişim göstermektedir. Yedikır Barajı'nın üst kısımlarında Ts değerlerinin alt ve yan kısımlarına göre daha yüksek olduğu tespit edilmiştir. Barajın üst kısımlarında Ts değerlerinin yüksek olması, kot farkından dolayı bu alanların sulanamamış olduğunu ve bu nedenle bitki vejetasyonun daha az olduğunu ifade etmektedir. Barajın alt ve yan kısımlarında uydu görüntüsünün çekim tarihi olan 25 Haziran 2013 tarihinde barajdan alınan su ile sulanarak yetiştirilen şeker pancarı ve mısır bitkileri geliş̧me dönemlerinde, ayçiçeği, arpa, soğan ve patates bitkileri orta dönemlerinde, buğday bitkisi ise son dönemlerindedir. Su varlığı nedeniyle barajın alt ve yan bölgelerinde vejetasyonun yüksek olmasıly birlikte Ts değerlerinin daha düşük olduğu tespit edilmiştir. Bafra Ovası'nı kapsayan Şekil 5'de tarım arazilerinin Ts değerleri genel olarak 290.0 ile $302.0 \mathrm{~K}$ arasında değişim göstermektedir. Ovada sağ sahil ve sol sahilde kalan tarım arazileri incelendiğinde, ortalama Ts değerlerinin hemen hemen aynı olduğu gözlemlenmiştir.

Bafra Ovas1 ve Suluova'ya ait Ts haritaları karşılaştırıldığında, Bafra Ovası'ndaki Ts değerlerinin genel olarak daha düşük olduğu tespit edilmiştir. Çalışmada Samsun ve Amasya'nın Ta değerleri sırasıyla 25.05 ve $30.7{ }^{\circ} \mathrm{C}$, RH değerleri ise sirasiyla $\% 67.2$ ve 25.5 olarak Çizelge 1'de verilmiştir. Düşük Ta, yüksek RH ve Bafra Ovası'nda görülen yarı nemli iklim tipi, Ts değerlerinin Suluova'ya göre neden daha düşük olduğunun göstergesi olarak sayılabilir.

\subsection{Sicak ve soğuk hücre bulgulart}

Amasya'y1 ve Samsun'u kapsayan uydu görüntülerinden sıcak hücre seçimi için oluşturulan filtrelenmiş yüzey sıcaklığı haritaları sırasıyla Şekil 6 ve 7 'de verilmiştir. Şekil 6'da Ts haritaları NDVI $<0.16$ ve Ts $>307.0 \mathrm{~K}$ koşulu ile filtrelenmiştir. Sonuç olarak hücre sayısı azaltılan filtrelenmiş Ts haritasından Suluova için sicak hücrenin NDVI ve Ts değerleri sirasiyla 0.15 ve $310.71 \mathrm{~K}$ olarak bulunmuştur. Şekil 7'de ise Ts haritaları NDVI $<0.2$ ve Ts $>300.0 \mathrm{~K}$ koşulu ile filtrelenmiştir. Bafra için filtrelenmiş Ts 


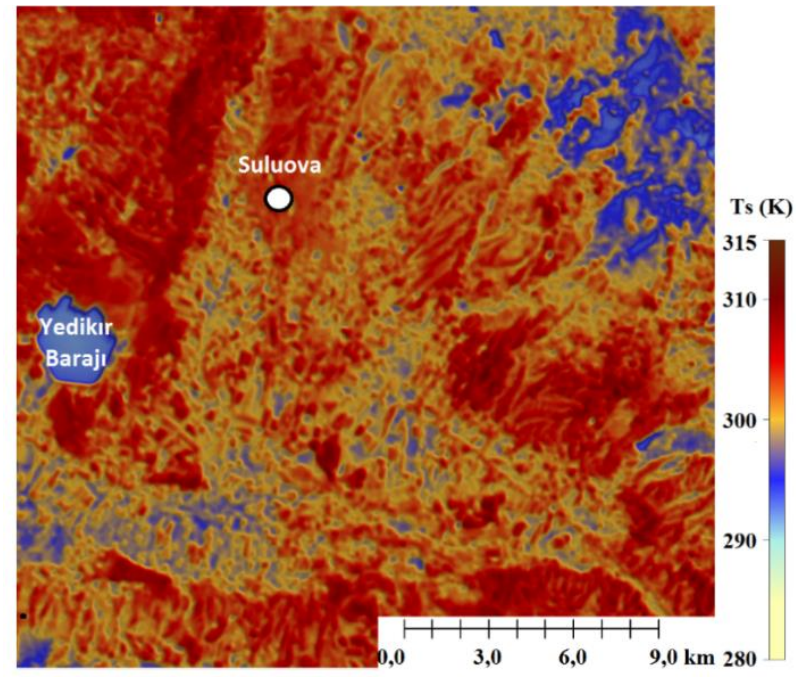

Şekil 4. Suluova'yı kapsayan uydu görüntüsünden elde edilen çalışma alanına ait Ts haritası.

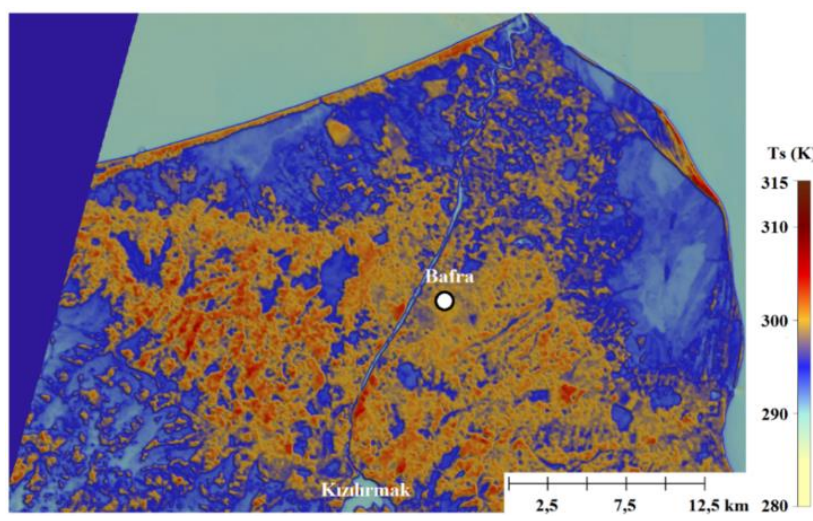

Şekil 5. Bafra'yı kapssayan uydu görüntüsünden elde edilen çalışma alanına ait Ts haritası.

haritasından seçilen sıcak hücrenin NDVI değeri 0,17 ve Ts değeri $301.54 \mathrm{~K}$ olarak belirlenmiştir.

Gowda ve ark., (2008a)'de Texas High Plains'de yapılan bir çalışmada, 27 Haziran ve 29 Temmuz 2005 tarihli Landsat 5 uydu görüntülerinden elde edilen sıcak hücre Ts değerleri sirasıly 308.0 ve $315 \mathrm{~K}$ ve Elarab (2016)'da yapılan bir çalışmada Utah'da 9 Haziran 2013 tarihli ve California'da 9 Ağustos 2014 tarihli uydu görüntülerinden elde edilen sicak hücre değerleri sirasıyla 327.48 ve $322.88 \mathrm{~K}$ olarak tespit edilmiştir. Bilindiği gibi ET' nin sıfıra yakın olduğu sıcak hücrelerde Ts üzerinde hava sıcaklığı ve oransal nem değerleri büyük bir etkiye sahiptir. Bu kapsamda, yukarıda verilen literatürlerde belirtilen sıcak hücre değerleri çalışma alanlarının iklim özellikleri ve tarih bakımından değerlendirildiğinde, bu çalışmada Suluova için belirlenen sıcak hücredeki Ts değerlerinin literatürlerle uyumlu olduğu değerlendirilmiştir. Fakat yarı nemli bölgede yer alan Bafra için belirlenen sıcak hücreye ait Ts değerinin yukarıda verilen literatürlerle karşılaştırıldığında daha düşük olduğu değerlendirilebilir. Bazı çalışmalarda METRIC modelinin kurak ve yarı kurak bölgeler için daha doğru sonuçlar verdiği belirtilmektedir (Allen ve Bastiaansen, 2005; Tasumi ve ark., 2005; Trezza, 2006; Condrad ve ark., 2007; Hendrickx ve ark., 2007; Chávez ve ark., 2009). Bunun temel nedeninin bu tür iklimlerde, bazı dönemlerde $E T$ ' nin sifir olduğu sicak hücrenin bulunamamasidır

Suluova ve Bafra tarım arazilerini kapsayan uydu görüntülerinden elde edilen ve soğuk hücre seçimi amacıyla kullanılan filtrelenmiş Ts haritaları sırasıyla Şekil 8 ve 9'da verilmiştir. Filtreleme işlemlerinde ilk olarak Ts ve NDVI haritalarının tarım arazileri için en düşük ve en yüksek değerleri tespit edilmiştir. Şekil 8 'de Ts haritaları NDVI $>0.85$ ve Ts $<296.0 \mathrm{~K}$ koşulu ile filtrelenmiştir. Yaklaşı $8.1 \times 10^{9}$ adet hücreye sahip Landsat 8 uydu görüntüsünün hücre sayısı azaltılarak Suluova için soğuk hücrenin NDVI ve Ts değerleri sırasıyla 0.86 ve $294.59 \mathrm{~K}$ olarak tespit edilmiştir. Şekil 9 'da Ts haritaları NDVI $>0.85$ ve Ts $<293.0$ koşulu ile filtrelenmiştir. Sonuçta Bafra için soğuk hücrenin NDVI ve Ts değerleri sırasıyla Bafra için 0.88 ve $292.16 \mathrm{~K}$ olarak elde edilmiştir. Gowda ve ark., (2008)'de Texas High Plains'de yapılan bir çalışmada 27 Haziran ve 29 Temmuz 2005 tarihli uydu görüntülerinden elde edilen soğuk hücrelerdeki Ts değerleri sırasıyla 291.6 ve 291.4 K ve Elarab (2016)'da kurak bölgelerde bulunan Utah ve California'da yapılan bir çalışmada 9 Haziran 2013 tarihli ve 9 Ağustos 2014 tarihli uydu görüntülerinden elde edilen soğuk hücre değerleri sirasıyla $308.48 \mathrm{~K}$ ve $305.07 \mathrm{~K}$ olarak tespit edilmiştir. Bu kapsamda çalışmada yarı kurak ve yarı nemli iklimlere sahip bölgeler için belirlenen soğuk hücredeki Ts değerlerinin literatürlerle uyumlu olduğu değerlendirilebilir. Soğuk hücre değerlerinde bulunan farkl1lıklar iklim, bitki örtüsü ve mevsimsel farklarla yeterli düzeyde açıklanabilmektedir.

Samsun ve Amasya'nın Ta değerleri Çizelge 1'de surasiyla 25.05 ve $30.7^{\circ} \mathrm{C}$, RH değerleri sirasıyla $\% 67.2$ ve 25.5 olarak verilmiştir (VPD değerleri sırasıyla 1.04'e 3.29). Çalışma kapsamında soğuk hücre için belirlenen Ts değerleri Suluova ve Bafra için sırasıyla 294.59 ve $292.16 \mathrm{~K}$ 'dir. Buna göre soğuk hücreye ait yüzey sıcaklığı ile Ta arasındaki fark (Ts-Ta) Suluova ve Bafra için sırasıyla -9.11 ve $\quad-5.89{ }^{\circ} \mathrm{C}$ olarak hesaplanmıştır. 


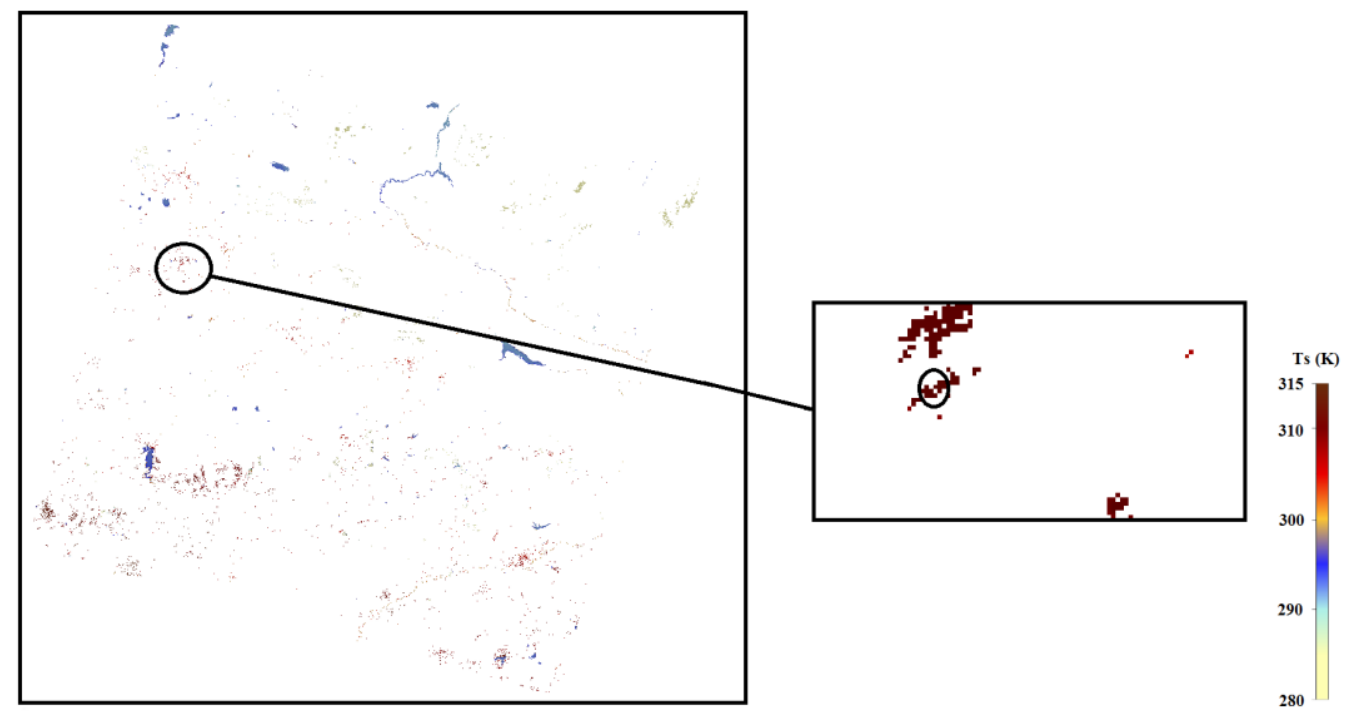

Şekil 6. Amasya merkezli uydu görüntüsünden sıcak hücre seçimi için oluşturulan filtrelenmiş Ts haritası.

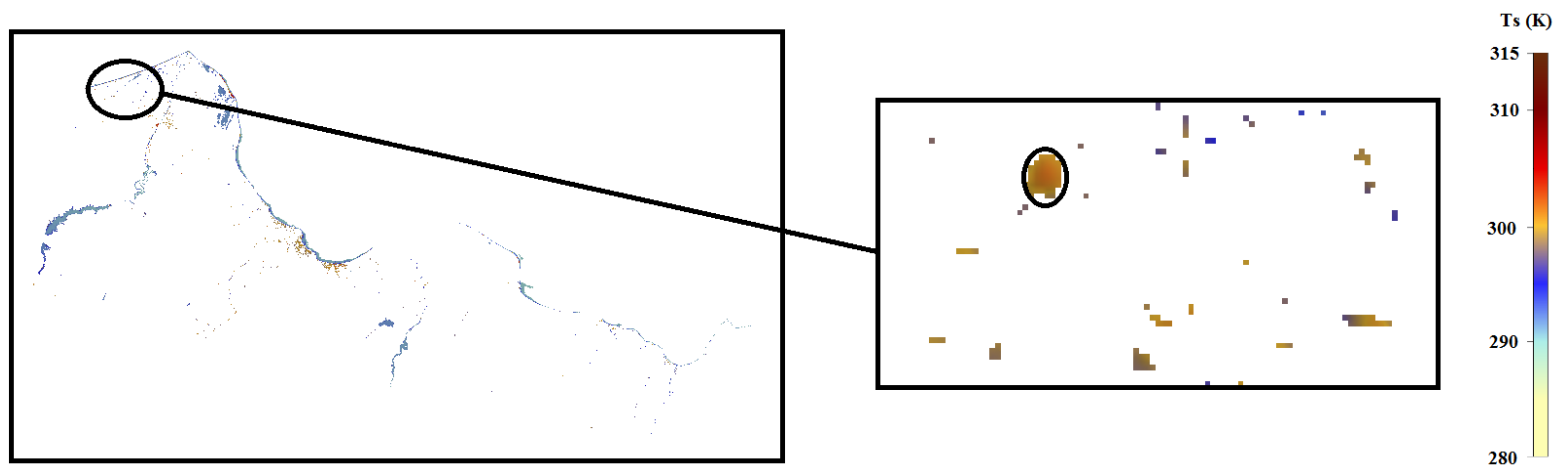

Şekil 7. Samsun merkezli uydu görüntüsünden sıcak hücre seçimi için oluşturulan filtrelenmiş Ts haritası

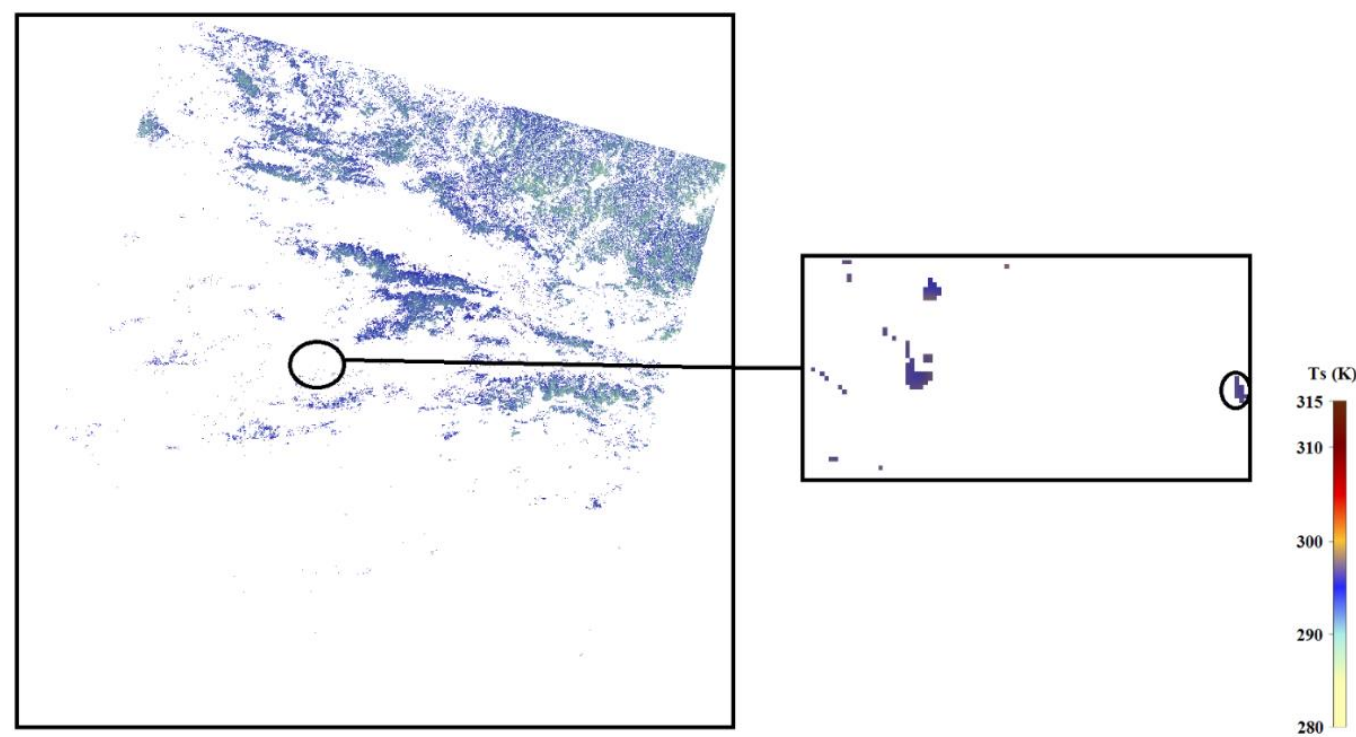

Şekil 8. Amasya merkezli uydu görüntüsünden soğuk hücre seçimi için oluşturulan filtrelenmiş Ts haritası. 


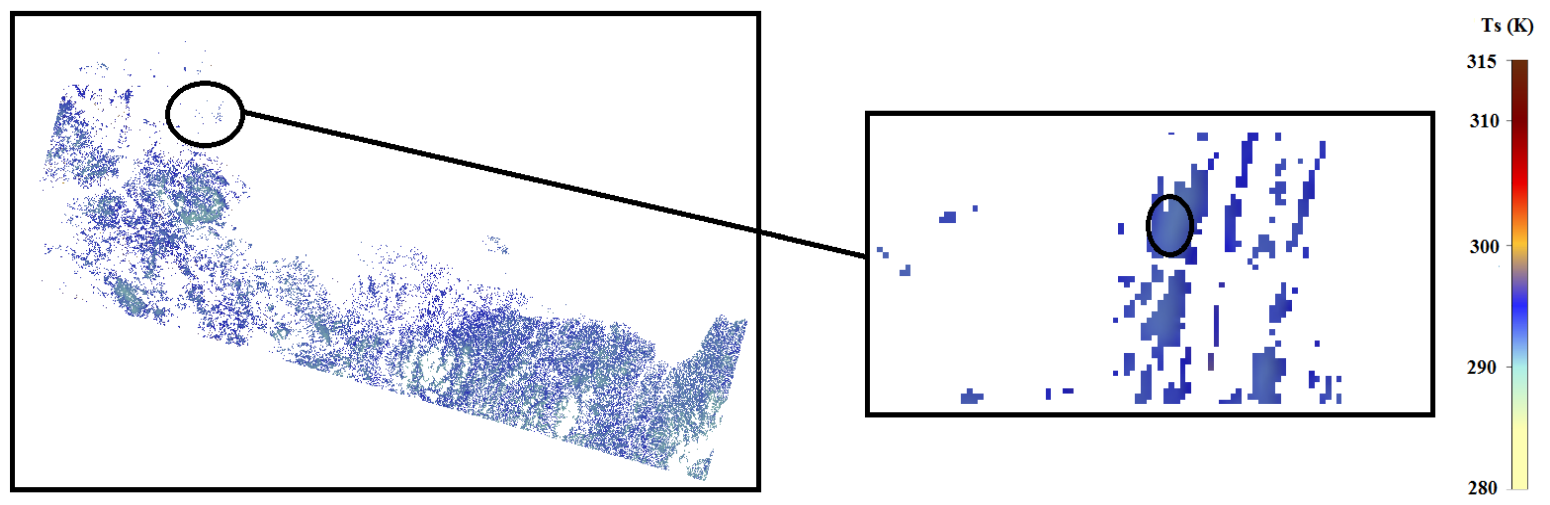

Şekil 9. Samsun merkezli uydu görüntüsünden soğuk hücre seçimi için oluşturulan filtrelenmiş Ts haritası.

Soğuk hücre Ts'nin düşük, NDVI'ın yüksek ve ET’nin potansiyel düzeyde olduğu su eksikliğinin olmadığ parsellerden seçilmektedir. Idso ve ark. (1981), Idso 1982, Pinter ve Reginato (1982) ve Howell ve ark., (1984) su eksikliğinin olmadığı bitkilerde, TsTa değerlerinin negatif değerler aldığı ve VPD değerleri değişse bile Ts-Ta'nın doğrusal olarak değişim gösterdiği belirtilmiştir. Buna göre Suluova ve Bafra için bulunan Ts-Ta değerleri ve soğuk hücre değerleri verilen literatürlerle uyumludur. Uydu görüntüsünün çekim saati sırasında Bafra'ya göre Suluova'da Ta'nın daha yüksek ve RH'nin daha düşük olması düşük TsTa'nın bir sonucudur. Çünkü kurak ve yarı kurak iklime sahip bölgelerde atmosferin nem talebi daha fazladır. $\mathrm{Bu}$ durum Ts'yi ve transpirasyonu artırmakta, dolayısıyla da ET'nin artmasına yol açmaktadır. Ayrıca Idso ve ark. (1981) ve Jackson ve ark. (1981)'de Ts-Ta değerleri sıfira yaklaștıkça su eksikliğinin azaldığı belirtilmiștir. Bafra'da Ts-Ta değerinin Suluova'ya göre sıfira daha yakın olduğu tespit edilmiştir.

Çalışmada Bafra ovasından seçilen sıcak hücre değeri Suluova için seçilen sıcak hücreye göre daha düşüktür. Sıcak hücredeki Ts-Ta değerleri Suluova için $7.05{ }^{\circ} \mathrm{C}$ iken Bafra için $3.49{ }^{\circ} \mathrm{C}$ olarak hesaplanmıștır. Sicak hücre Ts'nin yüksek, NDVI'ın düşük ve ET'nin 0'a yakın olduğu parsellerden seçilmektedir. Idso ve ark. (1981), Idso 1982, Pinter ve Reginato (1982) ve Howell ve ark. (1984)'de su eksikliği olan bitkilerde VPD değeri değişse bile Ts-Ta değerinin değişim göstermeyip sabit kaldığı belirtilmiştir. Uydu görüntüsünün çekim saati sırasında iki bölgedeki Ta ve RH farklılığı Ts-Ta'lar arasındaki farklılığın bir sonucu olarak sayılabilse de, yarı nemli bölgelerde ET nin sıfir olduğu bir alanın belirlenmesi yılın her döneminde olanaklı değildir.

\section{4. Çalışma alanının evapotranspirasyon haritaları}

Çalışmada 25 Haziran 2013 tarihli Landsat 8 uydu görüntülerinden elde edilen ET haritalarından çalışma alanları olan Suluova ve Bafra Ovası işaretlenerek kesilmiş ve sırasıyla Şekil 10 ve 11'de verilmiştir. Şekil 10 ve 11 'de ET değerlerinin yüksek olduğu alanların, NDVI değerlerinin yüksek ve Ts değerlerinin düşük olduğu olduğu tespit edilmiştir. Bafra Ovası'nda ET değerleri genel olarak 0.0 ile $6.0 \mathrm{~mm}$ gün $^{-1}$ arasında, Suluova'da ise 0.0 ile $10.0 \mathrm{~mm}_{\text {gün }}{ }^{-1}$ arasında değişim göstermektedir. Allen ve ark. (2005)'de Idaho'da yapılan bir çalışmada, ET değerlerinin arazi kullanımına göre 0.0 ile $10.0 \mathrm{~mm}$ gün $^{-1}$ arasında değişkenlik gösterdiği belirtilmiştir. Singh ve ark. (2012) tarafindan verilen bir çalışmada ise, ET'nin 0.0 ile $8.0 \mathrm{~mm}$ gün ${ }^{-1}$ arasında bitki gelișme dönemlerine göre farklılık gösterdiği ifade edilmiştir. Çalışma alanında bulunan Yedikır barajının alt ve yan bölgelerinde ET değerlerinin daha yüksek olduğu gözlenmiştir (Şekil 10). Bunun nedeni belirtilen bölgelerde uydu görüntüsünün çekim tarihine yakın bir zamanda barajdan alınan su ile sulama yapılması olarak düşünülebilir. Bafra ovasında ET değerleri genel olarak düşük olmasına rağmen sahile yakın kısımlarda yüksektir (Sekil 11). Sahile yakın bu alanlarda, sulak alanların bulunması ET'nin yüksek olmasına neden olmuştur.

Çalışma kapsamında daha düşük sıcak hücreye sahip Bafra Ovası'nda ET değerlerinin Suluova'ya göre genel olarak daha düşük olduğu gözlenmiştir. Çalışma alanında bulunan bazı tarım arazilerinde ET değerlerinin $\mathrm{ET}_{\mathrm{r}}$ değerlerine (Çizelge 1) yakın olması, bu alanlarda daha çok ET’nin potansiyel durumda olduğunu göstermektedir. $\mathrm{Bu}$ alanlar sulu tarım yapılan alanları kapsamaktadır. Ayrıca bu alanlara ait $\mathrm{T}_{\mathrm{s}}$ 'nin soğuk hücrede elde edilen Ts değerlerine yakın olduğu tespit edilmiştir. ET haritasında 0.0'a yakın olan yerler, ET değerlerinin en az düzeyde olduğu, daha çok sıcak hücreye yakın Ts değerlerine sahip bitki örtüsünden yoksun çıplak toprakları tanımlamaktadır. Suluova için elde edilen ET değerlerinin, Bafra Ovası için elde edilen ET değerlerinden genel olarak daha yüksek olduğu tespit edilmiştir. Bu durum Suluova ve Bafra'nın iklim verilerinin ve iklim tiplerinin farklı olmasından kaynaklanmaktadır. Uydu görüntüsünün çekim saatinde Bafra'da Suluova'ya göre Ta değeri daha düşük ve RH değeri daha yüksektir. Bu nedenle Bafra'da atmosferin nem talebi Suluova'ya göre daha düşüktür. 


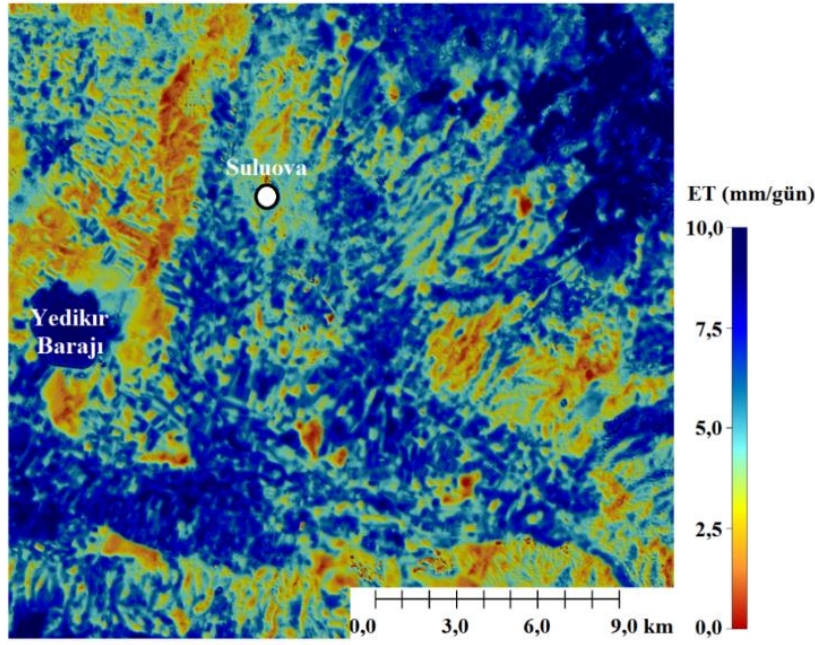

Şekil 10. Amasya merkezli uydu görüntüsünden elde edilen Suluova'ya ait ET haritası.

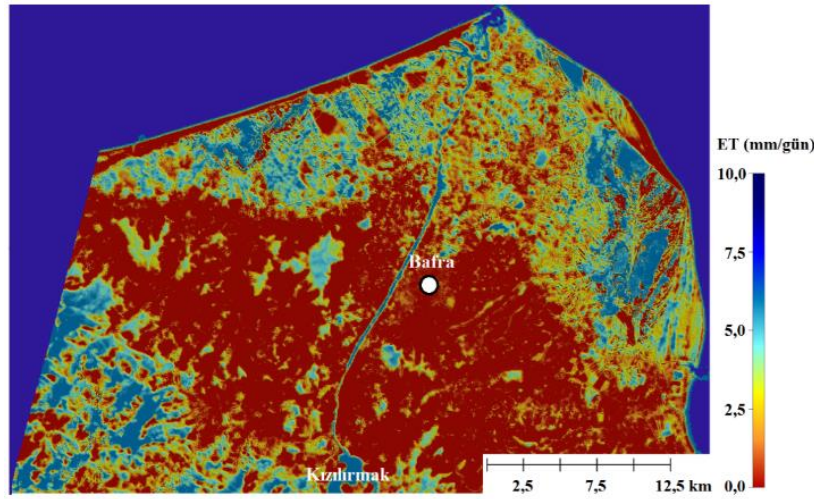

Şekil 11. Samsun merkezli uydu görüntüsünden elde edilen Bafra'ya ait ET haritası.

\section{Sonuç}

Evapotranspirasyonun haritalanması aşamalarından olan H'nin hesaplanması, diğer enerji dengesi bileşenlerinden daha karmaşık işlemler içermektedir. Genel olarak sıcak ve soğuk hücreye dayalı içsel kalibrasyonlar, $r_{a h}$ hesabındaki stabilite doğrulaması ve H' ye ulaşmadaki iterasyon işlemleri söz konusu hesaplama dizininin karmaşı bölümlerini olușturmaktadır. $\mathrm{Bu}$ nedenle termal banda sahip uydu görüntülerinden elde edilebilen ET haritaları, ancak sicak ve soğuk hücrenin hassas bir şekilde belirlenip H'nin doğru bir şekilde tahmin edilmesiyle mümkündür. Ayrıca yapılan çalışmalardan sıcak ve soğuk hücre seçiminde belirgin bir matematiksel yöntem olmadığı anlaşılmaktadır. Ancak bu çalışmada kullanılan Landsat 8 uydu görüntüsünün bir hücresinin $900 \mathrm{~m}^{2}$ 'lik bir alanı temsil ettiği ve Suluova ve Bafra tarım arazileri gibi büyük alanlarda uydu görüntüsünde binlerce hücrenin var olduğu göz önünde tutulduğunda, en doğru soğuk ve sıcak hücrelerin seçilmesinde filtreleme yapılmasının zorunlu olduğu söylenebilir.

$\mathrm{Bu}$ çalışmada Landsat 8 uydu görüntüleri kullanılarak elde edilen NDVI ve Ts haritalarına, çeşitli filtreleme işlemleri uygulanarak sicak ve soğuk hücre belirlenmiştir. $\mathrm{Bu}$ amaçla bu haritalarda çeşitli eşitliklerde NDVI değeri yüksek, Ts değeri düşük, ET'nin potansiyel düzeyde olduğu soğuk hücreler ve NDVI değeri düşük, Ts değeri yüksek, ET'nin en az düzeyde olduğu sıcak hücreler belirlenmiştir. Belirlenen bu hücreler kullanılarak ET haritaları oluşturulmuştur. Çalışmadan elde edilen sonuçlara göre, sıcak ve soğuk hücre seçiminde kullanılan bu filtreleme tekniği daha kolay, daha az işgücü, zaman ve daha yüksek doğrulukla ET haritalama olanăg sunmaktadır. Ayrıca sıcak hücrenin seçimi nemli ve yarı nemli bölgelerde ve kurak bölgelerde yağış olaylarının ardından belirlenmesi oldukça zordur. $\mathrm{Bu}$ nedenle konuyla ilgili gelecekte daha fazla çalışma yapılması önerilmektedir.

\section{Kaynaklar}

Allen, R. G.,Bastiaansen, W G. M., 2005. Special issue on remote sensing of crop evapotranspiration for large regions. Irrigation of Drainage Systems, 19: 207-210.

Allen, R. G., Tasumi, M., Morse, A., 2005. SatelliteBased Evapotranspiration by Metric and Landsat for Western States Water Management. Presented at the US Bureau of Reclamation Evapotranspiration Workshop Feb 8-10, - Ft. Collins, CO.

Allen, R.G., Walter, I.A., Elliott, R., Howell, T., Itenfisu, D., Jensen, M., 2005. The ASCE Standardized Reference Evapotranspiration Equation. Environmental and Water Resources Institute of the American Society of Civil Engineers January, Final Report.

Allen, R.G., Tasumi, M., Trezza, R., 2007. Satellitebased energy balance for mapping evapotranspiration with internalized calibration (METRIC)-Model. J. Irrig. Drain. Eng. ASCE 133 (4), 380-394.

Allen, R. G. Robison, C. W., Garcia, M., Trezza, R., Tasumi, M., Kjaersgaard J., 2010. ET $\mathrm{r}_{\mathrm{r}} \mathrm{F}$ vs NDVI Relationships for Southern Idaho for Rapid Estimation of Evapotranspiration. Report to IDWR.

Anonim, 2017. www.mgm.gov.tr

Bastiaanssen, W.G.M., Menenti, R.A., Feddes, Holtslag, A.A.M., 1998a. The surface energy balance algorithm for land (SEBAL). Part 1 formulation. J. Hydrol. 213: 198-298.

Bastiaanssen, W.G.M., Pelgrum, H., Wang, J., Ma, Y., Moreno, J. F., Roerink, G. J., Van Der Wal, T., 1998b. A remote sensing surface energy balance algorithm for land (SEBAL) 1. Formulation. Journal of Hydrology, 212-213:213-229.

Bastiaanssen W.G.M., Bos M.G., 1999. Irrigation performance indicators based on remotely sensed data: a review of literature. Irrigation and Drainage Systems, 13: 291-311.

Bastiaanssen, W.G.M., Bandara, K.M.P.S., 2001. Evaporative depletion assessments for irrigated watersheds in Sri Lanka. Irrigation Science, 21:1-15. 
Chávez, J.L., Gowda, P.H., Howell, T.A., Copeland K. S., 2009. Radiometric surface temperature calibration effects on satellite based evapotranspiration estimation. International Journal of Remote Sensing, 30,(9): 2337-2354.

Conrad, C., Dech, S.W., Hafeez, M., Lamers, J., Martius, C., Strunz, G., 2007. Mapping and assessing water use in a Central Asian irrigation system by utilizing MODIS remote sensing products. Irrigation and Drainage Systems, 21(3): $197-218$.

Elarab, M., 2016. The Application of Unmanned Aerial Vehicle to Precision Agriculture: Chlorophyll, Nitrogen, and Evapotranspiration Estimation. Utah State University, Doctor of Philosophy.

Gowda, P. H., Chávez, J. L. Howell, T. A., Marek, T. H., New, L. L., 2008a. Surface Energy Balance Based Evapotranspiration Mapping in the Texas High Plains. Sensors 8(8): 5186-5201; doi:10.3390/s8085186.

Gowda, P. H., J.L. Chávez, P.D. Colaizzi, S.R. Evett, T.A. Howell,, Tolk, ,J.A., 2008b: ET Mapping for agricultural water management: present status and challenges. Irrigation Science J. 26(3): 223-237.

Gowda, P. H., Howell T.A, Paul G., Colaizzi P.D., Marek T. H., 2011. SEBAL for estimating hourly ET fluxes over irrigated and dryland cotton during BEAREX08. World Environmental and Water Resources Congress. ASCE.

Hanson, R.L., 1991. Evapotranspiration and droughts. In: Paulson RW, Chase EB, Roberts RS, Moody DW, Compilers, National Water Summary 1988-89hydrologic events and floods and droughts: U.S. Geological Survey Water-Supply Paper 2375, pp 99-104.

Hendrickx, J.M.H., Kleissl, J., Vélez, J.D.G., Hong, S., Duque, J.R.F., Vega, D., Ramírez, H.A. M., Ogden, F.L., 2007. Scintillometer networks for calibration and validation of energy balance and soil moisture remote sensing algorithms. Algorithms and Technologies for Multispectral, Hyperspectral, and Ultraspectral Imagery XIII, 65650W, Orlando, Florida, USA, doi:10.1117/12.718124.

Howell, T.A., Hatfield, J.L., Yamada, H., Davis, K.R., 1984. Evaluation of cotton canopy tempature to detect crop Water stress. Transactions of the ASAE. $27 \quad$ (1): $\quad$ 0084-0088. (doi: 10.13031/2013.32740).

Idso, S.B., Jackson, P.J., Pinter, J.R., Reginatoi R.J. Hatfield, J.L., 1981. Normalizing the stress degree day parameter for environmental variability. Agricultural Meteorology, 24: 45-55.

Idso, S. B., 1982. Non-water-stressed baselines: A key to measuring and interpreting plant water stress. Agricultural Meteorology, 27: (1-2), 59-70.

Jackson, R.D., Idso, S.B., Reginato, R.J., Pinter, P.J., 1981. Crop canopy temperature as a crop water stress indicator. Water Resour. Res., 17:1133-1138.
Kamble, B., Kilic, A., Hubbard, K., 2013. Estimating Crop Coefficients Using Remote Sensing-Based Vegetation Index. Remote Sens. 5, 1588-1602, doi:10.3390/rs5041588.

Kjaersgaard, J.H., Allen, R.G., Garcia, M., Kramber, W., Trezza, R., 2009. Automated Selection of Anchor Pixels for Landsat based Evapotranspiration Estimation, World Environmental and Water Resources Congress: Great Rivers ASCE, 44004410.

Mallick, J., Kant, Y., Bharath, B.D., 2008. Estimation of land surface temperature over Delhi using Landsat-7 ETM+ J. Ind. Geophys. Union, 12(3): 131-140.

Pinter Jr., P.J., Reginato, R.J., 1982. A thermal infrared technique formonitoring cotton water stress and scheduling irrigation. Trans. ASAE, 25: 1651-1655.

Polhamusa, A., Fishera, J.B., Tu, K.P., 2013. What controls the error structure in evapotranspiration models? Agricultural and Forest Meteorology, 169:12- 24.

Sellers, P.J., Randall, D.A., Collatz, G.J., Berry, J.A., Field, C.B., Dazlich, D.A., Zhang, C., Collelo, G.D. Nounoua, L., 1996. A revised land surface parameterization (SiB2) for atmospheric GCMS, Part 1: Model formulation. J Clim., 9:676-705.

Singh, R. K., Irmak, A., 2011. Treatment of anchor pixels in the METRIC model for improved estimation of sensible and latent heat fluxes. Hydrological Sciences Journal, 56(5): 895906.

Singh, R.K., Liu, S., Tieszen, L.L., Suyker, A.E., Verma, S.B., 2012. Estimating seasonal evapotranspiration from temporal satellite images. Irrigation Science, 30(4): 303-313.

Sobrinoa, J.A. Jime'nez-Muñoza, J.C., Paolinib, L., 2004. Land surface temperature retrieval from LANDSAT TM 5. Remote Sensing of Environment, 90:434-440.

Tagem, 2016. Türkiye'de Sulanan Bitkilerin Bitki Su Tüketim Rehberi. Ankara.

Tasumi, M., Allen, R. G., Trezza, R., 2008. At-Surface Reflectance and Albedo from Satellite for Operational Calculation of Land Surface Energy Balance. Journal of Irrigation And Drainage Engineering, 13:2(51):1084-0699.

Tasum1, M., Trezza, R., Allen, R.G., Wright, J.L., 2005. Operational aspects of satellite-based energy balance models for irrigated crops in the semi-arid U.S. Irrigation and Drainage Systems, 19: 355-376.

Trezza, R., 2006. Estimation Of Evapotranspiration From Satellite-Based Surface Energy Balance Models For Water Management In The Rio Guarico Irrigation System, Venezuela, AIP Conference Proceedings 852, 162; doi: http://dx.doi.org/10.1063/1.2349340. 